$$
\text { ベントナイトゲルのすべり破壊* }
$$

$$
\text { 後 藤 廉 平** 清 水 清*** }
$$

\title{
Slip Fracture of Bentonite Gels
}

\author{
by \\ Rempei Goтон \\ (Institute for Chemical Research, Kyoto University, Takatsuki) \\ and Kiyoshi Shimizu \\ (Hokkaido Gakugei University, Hakodate)
}

\begin{abstract}
Gotoh and $\mathrm{Hirai}^{1)}$ found that the blocks of bentonite hydro-gels showed clear slip bands under critical pressure and the bands inclined at $45^{\circ}$ in the direction of the force given. The slip patterns could not be observed with the specimens treated at above $800^{\circ} \mathrm{C}$ or with those dispersed in organic liquids. Gotoh, Hanai and Aida ${ }^{2)}$ investigated the viscoelastic behavior of the bentonite gels with the cone and plate viscometer and found that the gel slipped at certain critical shear stress.

In this report, the critical shear stress at which the slip bands appear was measured at various concentrations of Wyoming bentonite dispersed in water. The critical shear stress was observed with the following three kinds of method; (1) a compression method (Fig. 1), (2) a cone and plate viscometer method and (3) a two surface shearing box method. Fig. 2 shows a typical slip band observed by the compression method. Fig. 3 shows the viscoelastic behavior and slip of the bentonite gel observed at various shearing loads. Fig. 4 shows the relation between the critical stress and the concentrations. The results obtained by the three kinds of method fall on the same line which shows a characteristic curve analogous to the relation between the elasticity of gels of high polymers and their concentrations ${ }^{3}$. It has been shown that the instantaneous elasticity of the bentonite gels shows also the same tendency with respect to their concentrations.

These results suggest that the bentonite gels has a network structure analogous to that of high polymers, but that the binding force is very weak in comparison with that of polymers. Further, it has been observed that a polarized light can pass through a thin film of the bentonite gel placed between two parallel glass plates at the instant when the plates are sheared (Fig. 6). This result suggests that the bentonite particles can be oriented under shearing stress, and such orientation may make the bentonite gels easy to slip.

(Received Dec. 1, 1964)
\end{abstract}

\section{1 緒 言}

さきに，後藤および平井はベントナイト一水系ゲル の角柱を軸方向に圧縮するとき, 力の方向に対して $45^{\circ}$ 傾いたすべり線が現われることおよびての性質がベン トナイトに熱処理をしたり，有機液体を媒質に用いた りすると消失する事実について報告した。また，後藤， 花井，相田らはベントナイトゲルの粘弹性について観 察して, ある限界ずり応力の下に不連続的すべりを生 ずることを認めた。

本報においては, ベントナィトの|山柱を用いて, 上

* 原稿受理 嘫利139件12 1 日

** 正会員 京都大学化学研究芹 高斯书大学的

$* * *$ 北海道学芸大学函館分校 函館市八僲町
記のすべり破壊を生ずる限界応力と濃度との関係を観 察し，円錐一平坂型粘度計ならびに引抜きせん断試験 によって得られる測定值とを比較した結果について述 ベる.

\section{$2 \cdot 1$ 試料}

Wyoming ベントナイト $400 \mathrm{~g}$ を $20 l$ の水中に攪 拌しながら分散させ，7 日間放置した後その上澄液の $2 / 3$ とり, $95^{\circ} \mathrm{C}$ 以下温度て加熱濃縮して, 種々の濃 度のゲルを得た，実験に用いた濃度範囲は 7〜 80wt\% であった。

\section{$2 \cdot 2$ 試料の大きさと成形法}

しんちゅう製円筒に試料を充てんし，同心円柱で押 
し出した，その直径や高さを変えて測定した結果，直 径が高さよりも小さいか，または等しければ，単位断 面積当りの破壤限界荷重は大きさ関せず一定となる ととな確かめたので，乙の契験では，直洤ならびに高 さがそれる゙れ $2.50 \mathrm{~cm}$ と $0.74 \mathrm{~cm} の 2$ 種類のもの軓試料 として用いた。（あまり高さを增すと濃度か稀欂な埸 合には自重で変栏するととがある）

\section{$2 \cdot 3$ 破壊限界応力の測定}

2.3.1 圧縮法 上記の方法で作った試料を Fig. 1 亿示すように台科にのせて上方からねじを用いてし

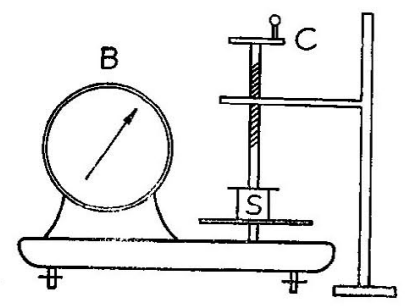

Fig. 1. Gompression method.

だい々圧絈すると台雬の目盛は初妙は增加するが，あ る圧力 $W\left(\mathrm{~g} / \mathrm{cm}^{2}\right)$ 飞達すると急江減少し炲め, との とき同時に試料面に Fig. 2 亿示すようなすべり線が

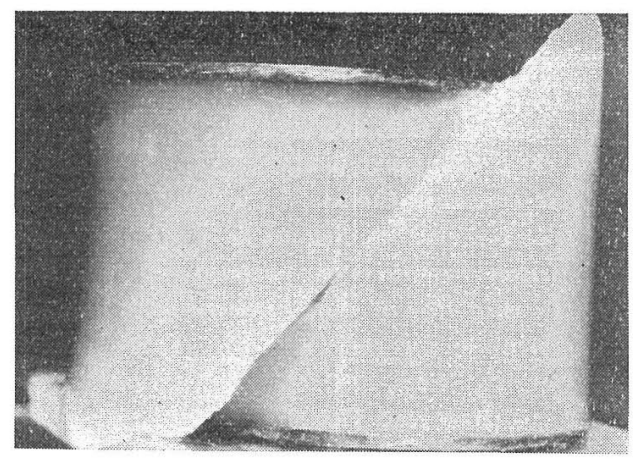

Fig. 2. Slip of a bentonite gel.

現われる，乙れをその眼度におりる限界圧力とし，45 方向のずり応力成分としてはその $1 / 2$ とった。

2.3.2 円触一平板粘度計法 円錐一平板粘度計 に試料を充てんし，てれに種々の徛重をかけて回転ず り応力を与觉ると Fig. 3 のように小荷重ではいわり る粘弾性的変化を示して回転するが，ある荷重を越す と不連続な回転を示しすべりが起きたととがわかる。

てのときの荷重汃ら破壊限界応力 $F_{\tau}\left(\mathrm{g} / \mathrm{cm}^{2}\right)$ を求めた。

2.3.3 引抜きせん断法 引抜き二面せん断器(切 口面積 $=3 \times 3 \mathrm{~cm}$ ) 試料を充てんし，引抜きわくを 可き出してれが動き始妨たとき応力(限界値) の変 化ならびに移動距離の変化を自動的に記録する．との せん断力が垂直に加えた圧力に無関係に一定となる範

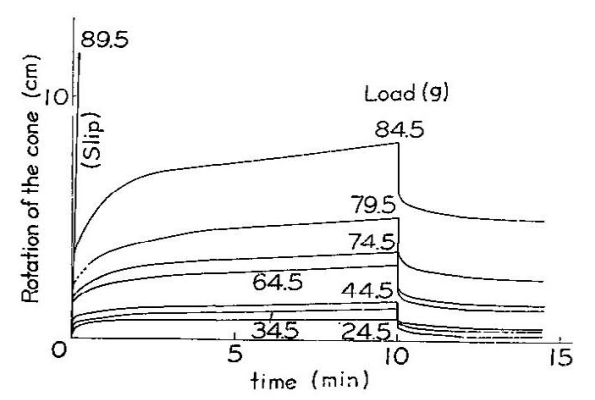

Fig. 3. Viscoelastic behavior and slip of a bentonite gel.

(Cone and plate viscometer)

围の金直圧の下にせん断力 $W_{0}\left(\mathrm{~g} / \mathrm{cm}^{2}\right)$ を測定して濃度 との関係を求めた。

\section{3 实 験 結 果}

\section{3 - 1 破壊限界圧力之濃度との関係}

Fig. 4 は，上記三つの方法で得た破壊限界值と濃

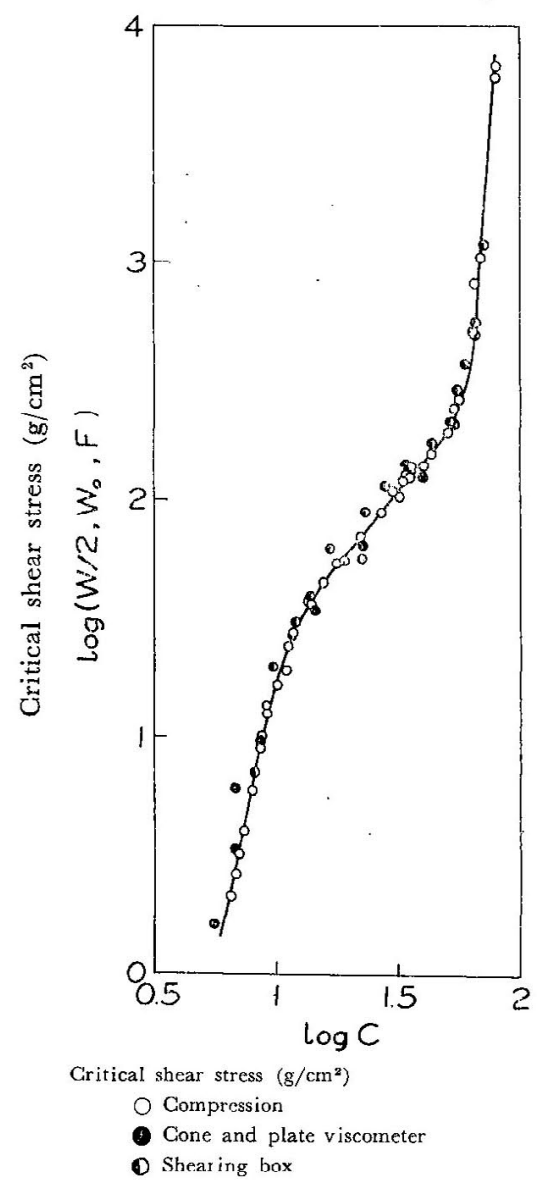

Fig. 4. Relation between the critical shear stress and concentrations of gels.

度との関係を一つの図にプロットしたもので三者が, よい一致を示している。すなわち，三つの方法で得ら 
れたずり応力は同一質のものであって，わつその破褧 限界值は，10\%以下では濃度に関し約 5.2 棐，10〜45 \%の䇢国では1.2乘，45\%以上では約12乘に比例して 变化することが示された。

なお，円錐一巫板法から，弾性定数，および粘性係 数の䟴度依存性度求めた結果，やはり10\%，45\%付近 に屈曲点が認められ，上の結果とそれぞれ対応関係が 成立しているととが推察される。なお，ての傾问は， 高分子ゲルの弾性と濃度との間にも認められていると ころである。

\section{$3 \cdot 2$ ベントナイトのすべりと配向性}

ベントナイトを 2 枚の透明板にはさみ，直交する 2 枚のポーラロイド板の間に置くと，すべりを与えたと きに䩾間的に光が通過する。

Fig. 5 は，ベントナイトをすべらせたときに偏光

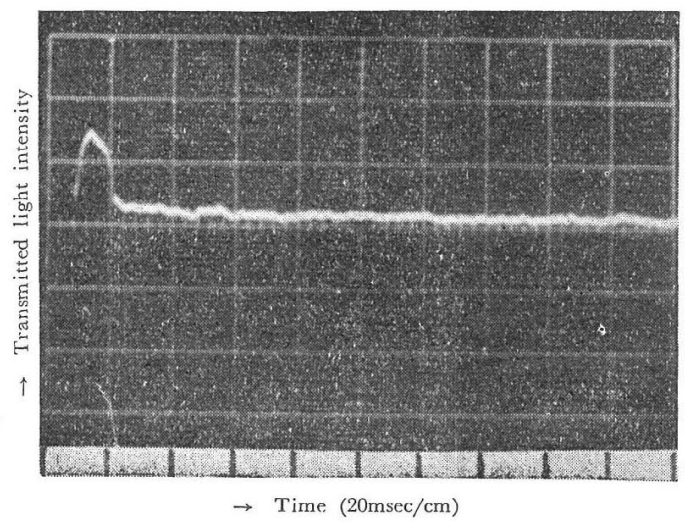

Fig. 5. Transmission of polarized light through a sheared film of bentonite gel.
板总透過した光量の桀化学オシロスコープで撮影した ものである。これは明らかにすべり龙こしたベント ナイトの偏平粒子が配向したこと, 拈よびそれが直ち に元にもどること六すものである.

\section{4 結 論}

ベントナィトのすべりは，弾性変形の後，最大ずり ひずみ力の方向に起とる一種の構造破塤現象であって， 風状流動とは本筫的に区別される，ベントナイトゲル の弾性は高分子ゲル弾性と類似の濃度依存性を示し， 水和したベントナイト粒子が比較的弱い力で鎖状に連 結し，網目構造をとるものと考えられる. 力の方向に 刘して $45^{\circ}$ なすずへり面の現われるのは, ベントナイ トゲル特有のものではなく, 固体性物体に共通の現象 であるか特にベントナイトゲルの場合, 弱いひずみ力 で容易に起とることは，ベントナイト粒子が扁平な形 を持ち,ずり応力の方向に配列しゃすいととに関連す るものでないかと㫴えいる。

すべり破壊の限界ずり応力ならびに弾性が浱度に閹 してともに 3 段階に変化するととは網目棈造の形成過 程に関連するものと考えられる。

(炤和39年10月1日，第13回レオロシー討論会にて綪演）

\section{参考文 献}

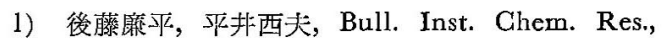
Kyoto Univ., 20, 48 (1950).

2) 後櫒麻平, 花井哲也, 相田博, 日化, 83, 32(1962).

3) 平州西夫，日化，74，541 (1953)；Bull. Inst. Chem. Res., Kyoto Univ., 33, 21 (1955).

4) Walter, A.T., J. Polym. Sci., 13, 221 (1954). 